DOI https://doi.org/10.18551/rjoas.2018-06.41

\title{
EFFECT OF APPLICATION OF GOOD GOVERNANCE, GOVERNMENT ACCOUNTING STANDARDS AND APPARATUS ON QUALITY OF FINANCIAL STATEMENTS
}

\author{
Indraswari I Gusti Agung Ayu Pramita \\ University of Udayana, Bali, Indonesia \\ Suputra I Dewa Gede Dharma \\ University of Udayana, Bali, Indonesia \\ E-mail: igaayupramitha@gmail.com
}

\begin{abstract}
The aim of this study is to obtain empirical evidence on the influence of good governance implementation and quality of apparatus on the quality of financial statements in Badung regency. Data analysis is done with multiples linear regression model. The results of the research showed that the implementation of good governance affect the quality of financial statements, meaning that if good governance is applied well and consistent then quality of financial report will increase. The quality of the apparatus affects the quality of financial statements, meaning that if the apparatus has the competence and good experience the quality of financial statements will increase.
\end{abstract}

\section{KEY WORDS}

Good governance, government, accounting standards, staff, financial statements.

The general purpose of the financial statements is to present information on the financial position, current cash, budget realization and financial performance of a reporting entity. In presenting the financial statements should be contain useful explanations for users of accounting information in assessing accountability for decision making. The form of government accountability to the people for the management of public funds, whether from taxes, levies or other transactions, is presented in the government's financial report (Mahmudi, 2010). Local governments capable of realizing transparency and accountability in the management of regional finances as indicated in Government Regulation no. 71/2010 on Standards of the Accounting in Indonesian Government (SAP), relevant, reliable, comparable and understandable are qualitative characteristics criteria that must be met in the preparation of Local Government Financial Reports (LKPD) (Yusniyar1, Darwanis2, 2016). Badung Regency got disclaimer opinion in 2008 and unfair opinion in the year 2013. That predicate makes Badung Regency Government effort to improve the governance, application of SAP and quality of apparatus, so opinion obtained by Badung Regency continue to improve in the next year. Based on that phenomenon, the increase from financial report opinion of the Badung Regency Government indicates an effort to improve the quality of optimal in financial reports. The increase of opinion is a form of public financial accountability in accordance with Government Regulation No. 24 of 2005.

The quality of LKPD is influenced by several factors, including the implementation of good governace, the application of SAP and the quality of government apparatus or Human Resources (Bastian, 2007); (Deddi, 2009); (Azlim, Darwanis, \& Bakar, 2012); (Sukmawaningrum, 2012) (Choirinisah, 2012); (Darman, 2015); (Efanita, 2013); (Irwan, 2011); (Sudiarianti, Ulupui, \& Budiasih, 2015). HR is an indispensable organizational wheel drive in an effort to realize its vision and mission objectives (Sudarmanto, 2014: 76). The role of human resources in creating quality financial reports is the most important factor because the application of SAP is done by human or human resources, as stated by (Payaman, J, 2005 ) in the process of preparing financial reports requires human resources who have competence, experience, education and understanding about governance accounting. (Bastian, 2007), (Roviyanti, 2014) and (Zeyn, 2011) declare that competent human 
resources in preparing financial reports in accordance with SAP will create quality financial reports. Competent human resources in their field are able to apply SAP in the preparation of quality government financial reports.

In a good governance realization or good governance is inseparable from technological and economic development which is the basic reference to realizing good local financial management. Implementation of good governance principles is needed to achieve effectiveness and efficiency in clean and transparent regional development. Implementation of good governance in a government is expected to create the achievement of the increasing value and optimally performance. Standards of the Accounting Government (SAP) is a principle used in preparing local government financial statements. The application of SAP is required to present an image of the financial capacity of a region to fund the implementation in the framework of regional development so that the management of the area can be analyzed. SAP is a requirement that must be done in an effort to improve the quality of the government's financial statements.

The existence of human resources / human resources (in this case the local government apparatus) is very influential on improving accountability of financial statements, because with the existence of good government apparatus then the presentation of financial statements will increase. Especially if supported by the existence of a very adequate capability possessed by the government apparatus in the preparation of financial statements. Parkinson (2012) stated that self-qualified human resources are in essence competent and have technical skills because they have the knowledge and skills to achieve the agreed outcomes and achieve the targets.

Research on the importance of quality apparatus in improving the quality of financial statements has been widely studied. (Irwan, 2011), (Sudiarianti et al., 2015), (Choirinisah, 2012) (Oktarina Raharjo, Si \& Andini, 2016) proves empirically that the quality of human resources has a positive and significant impact on the quality of financial statements. (Hullah, A.R. S. Pangemanan, S. Tangkuman, N., 2012) and (Siwambudi, Yasa \& Badera, 2017) concluded that human resources have a positive effect on the reliability of local government financial reporting. However, there are different results from the study (Ponaman, 2010) stating the capacity of human resources has no effect on the quality of financial statements. (Arfianti \& Kawedar, 2011) and (Sukmawaningrum, 2012) which conclude the competence of human resources does not affect the quality of financial statement information. The research conducted (Indriasari, D. Nahartyo, 2009) states that the capacity of human resources has no influence on the reliability of local government financial reporting.

\section{LITERATURE REVIEW}

The goal setting theory is based on evidence assuming that the target (ideas of the future, desired events) plays an important role in action. The goal setting theory is the individual model that wants to have a target, choosing a goal and ultimately will motivate for the achievement of goals / targets to be achieved (Birnberg, Mahennoko, 2011). The goalsetting theory requires that an individual be committed to a goal (Robbins, 2013).

Agency theory can occur in organizations including government organizations that focus on issues of information inequality between managers in this case (agency I government) and the public (represented by principals / councils). Principals should monitor and evaluate agency performance, so that organizational goals can be achieved effectively and efficiently and achieve public accountability (Lane, 2001); (Petrie, 2002). The relationship with agency theory is that governments acting as agents are obliged to do matters of interest and become the needs of government financial information users as principals (Faristina, 2011).

This theory is defined as the state of the manager is not motivated to individuals target but rather intended to the achievements that are generated and they get that directly interested in the organization. (Bartov, 2009) (Mardiasmo, 2007) describes within a public or environment organization governmental, the accountability is must by the government as a steward or something that has been entrusted to account for all forms of activities or 
community activities to provide a mandate or authorize by disclosing all forms of information contained in the accountability report that has been made, whether information in the form of success or failure that has been experienced by the organization.

Good governance is a way of how a trusted government that refers to the process of achieving its decisions and execution can be accounted for jointly in order for transparency to be maintained. In order to create a good governance, the government should be in line with the principles that apply to clean and corruption-free government management, collusion and nepotism, the existence of this case can also be caused by the low performance of government apparatus both in manage state budgeting and the public service, therefore the creation of good governance or good governance is expected to reduce the things that can trigger less optimal performance of the state apparatus.

Standards of the Accounting Government are the basic principles of accounting that should be applied in preparing financial statements in this case public sector organizations (Mahsun, M., Firma S., 2007). In applying SAP must comply with the Government Regulation, namely Government Regulation No. 71 of 2010 on Government Accounting Standards is a substitute of Government Regulation Number 24 Year 2005 regarding Government Accounting Standards. In fiscal year 2013, local governments are still implementing SAP based on Government Regulation Number 24 Year 2005 regarding Government Accounting Standards.

Human resources are the drivers and actors to run the organization in accordance with the targets to be achieved in a major organization of public sector organizations in order to achieve the goals already valid and planned. Organizations need the quality of human resources that can help in achieving the goals set by the organization.

Good governance is an organizer of solid and responsible development that is in line with effective democratic and market principles, avoids the mistakes of allocating investment funds and preventing corruption either as political or administrative, as well as running a budgetary discipline. But there are still many occurrences of violations and problems arising from the lack of optimal implementation of good governance in a government and cause conflict with good governance that is still commonplace in Indonesia, namely officials who are still concerned with personal interests compared with the interests of the people, presenting financial reports that are less precise and transparency in the presentation of less than optimal reports, the management of resources that are less effective and efficient, and accountability for every activity undertaken by the government is still weak and less than the maximum that causes good governance is still weak in applied in the government sector. Based on the description that has been described above so that the hypothesis in this study:

$\mathrm{H}_{1}$ : The implementation of Good Governance has a positive effect on the quality of financial statements.

Standards of the Accounting Government by (Bastian, 2007) in (Kusumah, 2013) are the principles of accounting application used in the preparation and presentation of financial reports in government. SAP is a standard that ensures the preparation of financial reports prepared to meet the qualifications of financial information useful to its users as a basis for decision making. Useful information is an indicator that the financial reports fit the proper information capacity and such principles that have been determined so that the financial reports are more qualified. SAP is a requirement that has the power of law in an effort to improve the quality of LKPD in Indonesia. The application of SAP has an impact on improving the quality of local government financial reports (Deddi, 2009); (Adhi \& Suhardjo, 2013). Based on the description that has been described above so that the hypothesis in this study:

$\mathrm{H}_{2}$ : Implementation of Government Accounting Standards has a positive effect on the quality of financial reports.

Quality apparatus is needed in order to manage a good local finance. Quality apparatus is supported with appropriate educational background in accounting and has a qualified experience in finance. This can be created by regular trainings and technical guidance to form human resources with competence and skills that will create quality financial reports. Professional government apparatus and competence in their field is needed 
by local government to move government role which then will do the basic task and the function perfectly and reach the target. With its competencies, professional government apparatus will be able to meet the standards and performance targets that have been set. Competent government officials in accounting (finance) are able to prepare financial statements according to SAP. The application of SAP requires the competence of civil servants to ensure that the financial statements prepared meet the qualifications of useful information. The research conducted (Oktarina Raharjo et al., 2016) states that the quality of government apparatus has a significant effect on the quality of SKPD financial report of Semarang City Government. The research (Adhi \& Suhardjo, 2013) also gives the same result that the Quality of Local Government Apparatus has significant influence on Quality of Kota Tua Government Financial Report. Based on the explanation described above, the following hypothesis in this study: statements.

$\mathrm{H}_{3}$ : The quality of the apparatus has a positive effect on the quality of the financial

\section{METHODS OF RESEARCH}

The data used in this study is the primary data. Survey method used in this research and conducted by way of questionnaire technique that is by passing list of statement filled by respondent to get the data. The population in this research is all of OPD in Badung Regency. Sample determination method used in this research is to use non-probability technique which is chosen by saturated sampling technique. The subject of the research that was taken as sample was KDP (Financial Administration Officer) of OPD in Badung Regency Government. The Data Analysis Techniques in this research is multiple linear regressions. Interpretation of the analysis of the data research is to answer the formulation of the problem in the study so that the research conclusions can be obtained. The indicators used for each research variable are:

Table 1 - Research Variables and Indicators

\begin{tabular}{|c|c|c|c|c|}
\hline Number & Variable & Indicators & $\begin{array}{l}\text { Measurement } \\
\text { Scale }\end{array}$ & Reference \\
\hline 1 & $\begin{array}{l}\text { Application of Good } \\
\text { Governance (X1) }\end{array}$ & $\begin{array}{ll}\text { - } & \text { Public Participation } \\
\text { - } & \text { Rule of law } \\
\text { - } & \text { Transparency } \\
\text { - } & \text { Responsiveness } \\
\text { - } & \text { Consensus-oriented } \\
\text { - } & \text { Equality } \\
\text { - } & \text { Accountability } \\
\text { - } & \text { Strategic Vision } \\
\end{array}$ & $\begin{array}{l}\text { Likert Scale } \\
\quad 1-5\end{array}$ & Dany (2015) \\
\hline 2 & Application of SAP (X2) & $\begin{array}{l}\text { PSAP Government Regulation Number } \\
712010\end{array}$ & $\begin{array}{c}\text { Likert Scale } \\
1-5\end{array}$ & $\begin{array}{c}\text { Irwan (2011) } \\
\text { Sudiarianti (2015) }\end{array}$ \\
\hline 3 & Quality of Aparatures (X3) & $\begin{array}{ll}- & \text { Quality and quantity } \\
\text { - } & \text { Roles and Responsibilities } \\
\text { - } & \text { Understanding } \\
\end{array}$ & $\begin{array}{l}\text { Likert Scale } \\
\quad 1-5\end{array}$ & $\begin{array}{c}\text { Fadila Ariesta } \\
(2013) \\
\text { Suwandi }(2016)\end{array}$ \\
\hline 4 & $\begin{array}{l}\text { Quality of Financial Statement } \\
\qquad(\mathrm{Y})\end{array}$ & $\begin{array}{ll}- & \text { Relevant } \\
\text { - } & \text { Reliably } \\
\text { - } & \text { Can be compared } \\
\text { - } & \text { Understandable }\end{array}$ & $\begin{array}{l}\text { Likert Scale } \\
\quad 1-5\end{array}$ & $\begin{array}{c}\text { Irwan (2011) } \\
\text { Sudiarianti (2015) }\end{array}$ \\
\hline
\end{tabular}

\section{RESULTS AND DISCUSSION}

The descriptive statistics are shown to obtain information about the characteristics of research variables obtained based on respondents' answers to each indicator. Information on the characteristics of variables in this study is presented in the descriptive statistics table shown in Table 2.

The results of multiple linear regressions testing in this study can be seen in the table. In the table can be seen the influence of the implementation of good governance, the application of SAP and the quality of apparatus on the quality of financial reports. 
Table 2 - Descriptive Statistics Test Results

\begin{tabular}{|l|c|c|c|c|}
\hline \multirow{2}{*}{ Variable } & \multirow{2}{*}{ Mean } & \multicolumn{2}{c|}{ Actual Range } & \multirow{2}{*}{ Standard Deviation } \\
\cline { 3 - 4 } & & Min & Max & \multirow{2}{*}{} \\
\hline Application of Good Governance & 47,35 & 18,40 & 60,51 & 13,90 \\
\hline Application of SAP & 47,58 & 17,00 & 60,90 & 15,67 \\
\hline Quality of apparatuses & 22,78 & 8,00 & 30,18 & 7,16 \\
\hline Quality of Financial Statement & 45,63 & 16,00 & 58,98 & 13,98 \\
\hline
\end{tabular}

Table 3 - Regression Analysis Results

\begin{tabular}{|c|c|c|c|c|c|c|}
\hline \multirow{2}{*}{$n / n$} & \multirow{2}{*}{ Models } & \multicolumn{2}{|c|}{ Unstandardized Coefficient } & \multirow{2}{*}{$\frac{\text { Standardized Coefficient }}{\text { Beta }}$} & \multirow[b]{2}{*}{$\mathrm{t}$} & \multirow[b]{2}{*}{ Sig } \\
\hline & & $B$ & Std. Error & & & \\
\hline \multirow{4}{*}{1} & (Constant) & $-4,710$ & 4,985 & & 0,945 & 0,351 \\
\hline & $\mathrm{X} 1$ & 0,309 & 0,093 & 0,307 & 3,310 & 0,002 \\
\hline & $\mathrm{X} 2$ & 0,446 & 0,082 & 0,500 & 5,435 & 0,000 \\
\hline & $\mathrm{X3}$ & 0,636 & 0,177 & 0,325 & 3,591 & 0,001 \\
\hline \multirow{2}{*}{2} & F.count & 37,425 & & & & \\
\hline & Sig.count & 0,000 & & & & \\
\hline \multirow{2}{*}{3} & $\mathrm{R}^{2}$ & 0,757 & & & & \\
\hline & Adjusted R & 0,737 & & & & \\
\hline
\end{tabular}

Interaction of the test results shown in the table to get moderation regression model in this research:

$$
Y=-4,710+0,309 \times 1+0,446 \times 2+0,636
$$

The results of the analysis shown in the table can be interpreted among others. The first hypothesis $(\mathrm{H} 1)$ states the implementation of good governance has a positive effect on the quality of financial reports. Regression analysis results in Table 5.6 shows the coefficient $\beta$ is 0.309 with a significance level of $0.002<0.05$ which means that the implementation of good governance has a positive and significant impact on the quality of financial reports.

Positive influence shows that if the government agency has applied the principles of Good Governance, then the quality of financial reports will continue to increase. This positive result shows that if the government in performing its functions and duties has applied the principles of Good Governance optimally, it will cause the government will run better including the quality of local financial management and financial information as a form of public accountability to the public. The results of this study are similar to the research conducted by (Oktarina Raharjo et al., 2016) that the implementation of good governance has a positive effect on the quality of financial statements. Research (Yusniyar1, Darwanis2, 2016) suggests that governance has a positive effect on the quality of financial statements. Tucker research (2015) states the implementation of good governance affects the quality of financial statements.

Based on the agency theory, there is a conflict of interest between the government (agent) and the principal (community) there is the issue of information inequality / asymmetry between the government and the community. The practice of financial reporting in public sector organizations is a concept that is based on agency theory. Governments acting as agents have an obligation to provide useful information to users of government finance information that acts as a principal in assessing accountability and making decisions.

The second hypothesis $(\mathrm{H} 2)$ states the application of SAP has a positive effect on the quality of financial statements. Regression analysis results in Table 5.6 describes the coefficient of $\beta$ is 0.446 with a significance level amount $0,000<0.05$ which means that the application of SAP has a positive and significant impact on the quality of financial statements. SAP is the accounting principles adopted in preparing and presenting government financial statements. If the government prepares financial reports based on SAP principles then the quality of financial reports will get better. The results of this study are in accordance with research conducted by (Oktarina Raharjo et al., 2016) which concluded that the application of SAP has a positive effect on the quality of financial reports. The results of the study 
(Sudiarianti et al., 2015) concluded that SAP has a positive effect on the quality of financial reports.

Based on the goal setting theory explains that goal setting will be able to improve work performance. Accountability demands for public institutions; local governments must be state the accountability of success or failure experienced by the agency should be published through transparent and accountable financial statements. With goal setting theory approach, local government financial report is assumed as local government goal, while SAP variable is a determinant factor, if SAP is applied well in institution then local government goal will be achieved. The third hypothesis $(\mathrm{H} 3)$ proves the quality of the apparatus has a positive effect on the quality of financial reports. Regression analysis results in Table 5.6 shows the coefficient of $\beta$ is 0.636 with a significance level of $0.001<0.05$. This means that the quality of the apparatus has a positive and significant effect on the quality of the financial reports. This is supported by the competence of the apparatus in the field of accounting, often following technical guidance and training, and has experience in the field of finance as an effort to improve the quality of self. Human resources or government apparatus quality can certainly produce quality financial reports. This research is in accordance with research conducted by Suwandi (2016) which concluded the quality of human resources take effect positive on the quality of local government financial statements. The results of this study are also the same or in line with research Nugraheni (2008) which states there is a positive relationship between the quality of human resources on the quality of financial reports.

Steward theory has a relationship between principal and steward in this case people and government because of human nature that can be trusted, able to act with full responsibility, have integrity, and honesty to other party. The government as a party who has a lot of information and is responsible for the trust that has been given the people have awareness in order to continue to realize and create transparency and accountability through the disclosure of good financial statements.

\section{CONCLUSION AND SUGGESTIONS}

Based on the results of the analysis and discussion results, this study then the conclusion is the implementation of governance positive effect on the quality of financial reports mean that if good governance applied properly and consistent then the quality of financial reports will increase. The application of SAP has a positive effect on the quality of financial reports, meaning that if the application of SAP has been applied properly and consistently then the quality of financial statements will increase. The quality of the apparatus has a positive effect on the quality of financial reports, meaning that if the government apparatus has good competence and experience then the quality of the financial statements will increase. Based on the results of the research, some suggestions can be submitted, among others 1) The results show that efforts are made to improve the implementation of good governance based on respondent's data focused on legal aspects, responsiveness and strategic vision. Therefore, the researchers suggest the need for evaluation such as forming public service information, held a socialization related vision of the government's mission in order to improve the quality of financial statements. 2) The results showed the efforts made for the application of SAP more increased based on the data of respondents should be focused on aspects of inventory recording. So, it is recommended that the inventory recording should be carried out based on the results of physical inventory per quarter. 3) The results showed the efforts made to improve the quality of apparatus based on the data respondents' answers focused to the competence, understanding the role and responsibility of the apparatus. So, it is recommended to hold training or technical guidance in accordance with the standards of competence demanded from each field of government apparatus in order to further improve the understanding of the apparatus to improve the quality of financial statements. 4) Based on the result from R-square still found other variables outside the model that can affect the quality of financial statements in addition to variables in this study. This opens the opportunity for those who will examine after this to trace and reflect other variables that could be used as factors that affect the quality of financial statements such as 
Government Internal Control System (SPIP) and utilization of information technology. 5) Limitations of this study are the sample used only in the OPD in Badung regency then the findings cannot be generalized in other areas. The sample used in this research is relatively small is 40 respondents. It is recommended for further research to try to use a wider sample with a larger number of respondents in order to describe the financial management in OPD.

\section{REFERENCES}

1. Mahmudi. (2010). Analysis of Local Government Financial Statements (Second Edition Vol.). UPP STIM YKPN Yogyakarta.

2. Yusniyar1, Darwanis2, S. A. (2016). Influence Implementation of Government Accounting System and Internal Control to Good ..., (July).

3. Bastian,I. (2007). Scope of Public Sector Accounting.

4. Deddi, N. (2009). Public Sector Accounting 2nd Edition.

5. Azlim, Darwanis, \& Bakar, U. A. (2012). The Influence of Good Governance and Implementation. The Influence of the Implementation of Good Governance and Government Accounting Standards on Quality of Financial Information SKPD In Banda Aceh City, 1 (1), 1-14.

6. Sukmawaningrum, T. (2012). Factor Factor Analysis Affecting Information Quality of Local Government Financial Statement. Thesis of Dponegoro University. Retrieved from http://eprints.undip.ac.id/35305/1/Skripsi_15.pdf

7. Choirinisah, F. (2012). Analysis of Factors Influencing Information Quality of Local Government Financial Statements (Empirical Studies of Regency / City Government in Riau Province). Institutional Repository.

8. Darman, S. (2015). The Effect of Implementation of Government Accounting Standards and Government Internal Control System on Quality of Financial Reports of Local Government Work Units in Kabupaten Aceh Utara. Journal of Master Degree in Graduate Accounting of Syiah Kuala University, 4 (4), 23-35.

9. Efanita, W. V. I. L. (2013). Influence of Implementation of Good Governmental Governance, and Government Accounting Standards on Quality of Government Financial Statements, 106-121.

10. Irwan. (2011). Effect of Source Competency Dayamanusia, Application of Government Internal Control System, and Application of Government Accounting Standards on Quality of Padang City Government Financial Statement. Universitas Gajah Mada.

11. Sudiarianti, N. M., Ulupui, I. G. K. A., \& Budiasih, I. G. A. (2015). The Influence of Human Resources Competency On Implementation Of Government Internal Control System And Government Accounting Standards And Its Impact On Quality Of Local Government Financial Report. Journal of Business and Management, 4 (1), 1-25.

12. Sudarmanto, 2014. Competency performance and development human resources : Theory, Measurement Dimensions and Implementation in Organizations. Yogjakarta: Pustaka Pelajar.

13. Payaman, J, S. (2005). Book Collection 1985 Simanjuntak, Payaman J. "Introduction to the economy of human resources / Payaman J. Simanjuntak "1985.

14. Roviyanti, D. (2014). The Influence Of Human Resource Competency And Application Of Regional Financial Accounting System To The Quality Of Local Financial Report. Journal of Accounting Universitasv Siliwangi.

15. Zeyn, E. (2011). The Influence of the Implementation of Good Governance and Government Accounting Standards on Financial Accountability. Trikonomika, 10 (1), 5262

16. Parkinson, J. 2012. Accounting for Process Cost System in New Zealand. The Journal of Law and Financial Manajement. Vol 11 Issue 2.

17. Oktarina Raharjo, K., Si, M., \& Andini, R. (2016). The influence of the application of government accounting standards, the quality of local government apparatus and good governance to the quality of financial statements in the city of Semarang, 2 (2). 
18. Hullah, A.R ,. S. Pangemanan, S. Tangkuman,. N., B. (2012). Effect of Human Resources, Utilization of Information Technology, Internal Control of Financial Reporting Dependability At North Sulawesi Government, Vol. 3.

19. Siwambudi, I. G. N., Yasa, G. W., \& Badera, I. D. N. (2017). Organizational Commitment As Moderate Effect of Human Resources and Internal Control System on Quality of Financial Statement. E-Journal of Economics and Business, 6.1, 385-416.

20. Ponaman, I. F. (2010). Irene Fransisca Ponaman, 68-80.

21. Arfianti, D., \& Kawedar, W. (2011). Analysis of Factors Affecting the Value of Local Government Financial Reporting Information (Study at Regional Device Work Unit in BatangRegency),1-31.

22. Indriasari, D. Nahartyo, E. (2009). Effect of Human Resource Capacity, Utilization of Information Technology, and Internal Control of Accounting, Against Value of Local Government Financial Reporting Information. Journal of Accounting Studies \& Research, 2 (2), 65-66.

23. Birnberg, Mahennoko, A. A. (2011). The Influence of Work Motivation and Organizational Commitment to the Performance of Finance Officers at Demak District Government. Diponegoro University.

24. Lane, J.-E. (2001). New Public Management - Book review. International Public Management Journal, 4, 115-118.

25. Petrie, M. (2002). A Framework for Public Sector Performance Contracting. A Framework for Public Sector Performance Contracting, 117-153.

26. Faristina, R. (2011). Factors Affecting the Reliability and Timeliness of Financial Reporting of Public Service Agency (Study on BLU in Semarang City). Diponegoro University.

27. Bartov, E. dan Cohen, D.A. 2009. The "Numbers Game" in the pre-and post SarbanesOxleyeras. Journal of Accounting, Auditing \& Finance. Vol. 24, No. 4 pp. 505-534.

28. Mardiasmo. (2007). Public sector accounting. Yogyakarta: Andi Yogyakarta.

29. Mahsun, M., Firma S., H. (2007). Public Sector Accounting (Issue 1). Yogyakarta: Yogyakarta BPFE.

30. Kusumah, A. A. (2013). The Effect of Implementation of Government Accounting Standards on Quality of Financial Statements, Volume 7 N, 157-175.

31. Adhi, D., \& Suhardjo, Y. (2013). The Effect of Implementation of Government Accounting Standards and Quality of Local Government Apparatus on Quality of Financial Statements (Case Study In Tual City Government), 5 (3), 1-19. https://doi.org/ISSN: 2252-7826.

32. Tucker, S.A. dan Cofsky, K.M. 2015. Competency-Based Pay on a Banding Platform. ACA Journal, Vol. 3. No. 1.

33. Nugraheni, P., \& Subaweh, I. (2008). The Effect of Implementation of Government Accounting Standards on Quality of Financial Statements. Journal of Economics and Business, 13 (1), 48-58. https://doi.org/10.1017/CBO9781107415324.004 